\title{
REVISTAMATĒRIA
}

ISSN 1517-7076 artigo e-11907, 2017

\section{Evaluation of the addition of glycerol to Cupriavidus necator culture medium over Poly(3-hydroxybutyrate) production}

\author{
Giannini Paszinick Apati ${ }^{1}$, Maikon Kelbert ${ }^{1}$,Bruna Regina Sombrio ${ }^{1}$, \\ Andrea Lima dos Santos Schneider ${ }^{1}$, Michele Cristina Formolo Garcia ${ }^{1}$, \\ Agenor Furigo Junior ${ }^{2}$, Ana Paula Testa Pezzin ${ }^{1}$
}

\footnotetext{
${ }^{1}$ University of the Joinville Region - UNIVILLE, Rua Paulo Malschitzki, 10 - Zona Industrial Norte - Cx Postal 246 CEP 89219-710 - Joinville/SC.

e-mail: giannini.apati@univille.br

${ }^{2}$ Federal University of Santa Catarina - UFSC, Dept. of Chemical Engineering and Food Engineering - Technological Center - CEP 88040-900 Florianópolis, SC.
}

\begin{abstract}
Glycerol was used as a source of additional carbon in the production of Poly(3-hydroxybutyrate) $(\mathrm{P}(3 \mathrm{HB}))$. The inverted sugar and glycerol concentrations and the temperature of the Cupriavidus necator culture medium were evaluated using a Central Composite Rotational Design (CCRD). The results showed that the increase in temperature and sugar concentration led to an increase in production and $\mathrm{P}(3 \mathrm{HB})$ accumulation and when $15 \mathrm{~g} \mathrm{~L}^{-1}$ of glycerol was added better results were obtained, however these were not considered statistically significant. The best results were obtained at $38^{\circ} \mathrm{C}$ and with $30 \mathrm{~g} \mathrm{~L}^{-1}$ of inverted sugar. Although not considered statistically significant, the addition of $15 \mathrm{~g} \mathrm{~L}^{-1}$ of glycerol increased the $\mathrm{P}(3 \mathrm{HB})$ accumulation percentage by $15 \%$, thus in kinetic terms, greater productivity was obtained in $0.32 \mathrm{~g} \mathrm{~L}^{-1} \mathrm{~h}^{-1}$ polymer. Larger scale assays are being conducted to verify if the addition of glycerol improves the thermal and mechanical properties of the synthesized polymer.
\end{abstract}

Keywords: Poly(3-hydroxybutyrate), Cupriavidus necator, glycerol.

\section{INTRODUCION}

Poly(3-hydroxybutyrate) - $\mathrm{P}(3 \mathrm{HB})$ - is a natural and biodegradable polyester from the polyhydroxyalkanoates (PHAs) family, synthesized and accumulated internally in diverse micro-organisms [1]. It is a photopolymer and is highly crystalline, rigid and brittle, which reduces its application, however, the addition of nucleating agents, plasticizers or other additives have been used to give new applications to $\mathrm{P}(3 \mathrm{HB})[2]$. According to Gumel et al. (2012) [3] the type of carbon source used as a substrate does not only affect the polymer produced in terms of physical-chemical and mechanical properties but also its yield and monomeric composition.

The $\mathrm{P}(3 \mathrm{HB})$ applications are the most diverse, being used for biodegradable packaging, agricultural product packaging for transporting young plants [4], tissue engineering, due to their biocompatibility, for manufacturing prostheses and other medical components as it does not generate toxic substances during degredation [5,6], for toothbrushes [7], in the formulation of capsules for the controlled release of pharmaceuticals and pesticides [8].

Most of the technologies so far implemented for the microbial production of PHA are not economically competitive with the production of synthetic plastics, although they are already commercially available. Therefore, efforts have been made to achieve more cost-effective and sustainable PHA production processes [9, 10]. Many researchers have been focusing on the use of low cost sugars as a source of carbon for an efficient PHAs [11] production. On the other hand, with the growing increase of biodiesel production, the cost of glycerin originating from the production process has been decreasing due to an increase in supply, often making its refinement process economically unfeasible. Silva et al. (2009) [12] have already indicated crude glycerol as being a promising source of abundant carbon for industrial microbiology.

Within this context, the aim of this study was to evaluate the use of glycerol as a source of additional 
carbon in the Cupriavidus necator medium culture in the production and accumulation of $\mathrm{P}(3 \mathrm{HB})$.

\section{MATERIALS AND METHODS}

\subsection{Experimental planning:}

The C. necator cells were cultivated in baffled $1.000 \mathrm{~mL}$ Erlenmeyer flasks containing $300 \mathrm{~mL}$ of Mineral Medium (MM). The concentrations of the inverted sugar carbon sources (glucose and fructose) (varying from 0 to $30 \mathrm{~g} \mathrm{~L}^{-1}$ ) and/or glycerol (varying from 0 to $30 \mathrm{~g} \mathrm{~L}^{-1}$ ) and culture medium temperature (varying from 28 to $38^{\circ} \mathrm{C}$ ) according to central composite rotational design (CCRD) $2^{3}$ with 3 central points. The culture media were maintained under stirring at $150 \mathrm{~min}^{-1}$, for $24 \mathrm{~h}$. The statistical analyses were conducted with the help of Statistica 7.0 software.

\subsection{CCRD validation:}

Assays were conducted, in triplicate, under conditions indicated by CCRD as the highest producer of $\mathrm{P}(3 \mathrm{HB})$

\subsection{Cell growth:}

Dry weigh was determined by using pre-weighed $2 \mathrm{~mL}$ Eppendorf tubes. $2 \mathrm{~mL}$ of culture broth was centrifuged at 9,000 rpm for $10 \mathrm{~min}$. The supernatant was discarded and the cell pellet was washed twice with distilled water. The cell pellet was dried $24 \mathrm{~h}$ at $60{ }^{\circ} \mathrm{C}$ and cooled down to room temperature in a desiccator. The weight difference was used to determine the dry biomass.

\subsection{Substrate consumption:}

Substrate consumption (glucose/fructose and glycerol) was verified by high performance liquid chromatography (HPLC) (Merck Hitachi model D-7000IF) with refractive index detector model RI-71 (Merck), with Transgenomic, model ICSep ICE-ION Column (protons exchange). The mobile phase was $8.5 \mathrm{mmol} . \mathrm{L}^{-1} \mathrm{H}_{2} \mathrm{SO}_{4}$ and the flow rate was $0.4 \mathrm{~mL} \cdot \mathrm{min}^{-1}$. The column temperature was maintained at $70{ }^{\circ} \mathrm{C}$ and the volume injection was $10 \mu \mathrm{L}$.

\subsection{P3(HB) determination:}

$2 \mathrm{~mL}$ of the medium was centrifuged and the cells were washed twice with distilled water, then submitted to methanolysis, according to the method based on Braunegg et al. (1978) [13], with modifications proposed by Brandl et al. (1995) [14]. The $\mathrm{P}(3 \mathrm{HB})$ was then dosed by gas chromatography.

\section{RESULTS AND DISCUSSION}

For evaluating temperature influence on the Cupriavidus necator DSM 545 culture medium and the influence of inverted sugar and glycerol concentrations a central composite rotational design was used.

Tab. 1 shows the 17 assays conducted under the experimental conditions used and the responses obtained in the experiments.

Table 1: Experimental conditions of design assays and responses in $\mathrm{Xt}\left(\mathrm{g} \mathrm{L}^{-1}\right), \mathrm{Xr}\left(\mathrm{g} \mathrm{L}^{-1}\right), \mathrm{P}(3 \mathrm{HB})\left(\mathrm{g} \mathrm{L}^{-1}\right)$.

\begin{tabular}{|c|c|c|c|c|c|c|}
\hline ASSAY & GLYCEROL & $\begin{array}{c}\text { INVERTED SUGAR } \\
\left(\mathrm{g} \mathrm{L}^{-1}\right)\end{array}$ & $\begin{array}{l}\text { TEMPERATURE } \\
\left({ }^{\circ} \mathrm{C}\right)\end{array}$ & $\begin{array}{c}X t \\
\left(g^{-1}\right)\end{array}$ & $\begin{array}{l}P(3 \mathrm{HB}) \\
\left(\mathrm{g} \mathrm{L}^{-1}\right)\end{array}$ & $\begin{array}{c}\text { ACUMULATED P(3HB) } \\
(\%)\end{array}$ \\
\hline 1 & 6.1 & 6.1 & 30.0 & 5.5 & 0.74 & 13.40 \\
\hline 2 & 23.9 & 6.1 & 30.0 & 5.3 & 0.84 & 15.93 \\
\hline 3 & 6.1 & 23.9 & 30.0 & 7.8 & 2.72 & 34.90 \\
\hline 4 & 23.9 & 23.9 & 30.0 & 6.9 & 2.07 & 28.25 \\
\hline 5 & 6.1 & 6.1 & 36.0 & 5.9 & 1.31 & 22.16 \\
\hline 6 & 23.9 & 6.1 & 36.0 & 6.1 & 1.51 & 24.76 \\
\hline
\end{tabular}




\begin{tabular}{|c|c|c|c|c|c|c|}
\hline ASSAY & GLYCEROL & $\begin{array}{c}\text { INVERTED SUGAR } \\
\left(\mathrm{g} \mathrm{L}^{-1}\right)\end{array}$ & $\begin{array}{l}\text { TEMPERATURE } \\
\left({ }^{\circ} \mathrm{C}\right)\end{array}$ & $\begin{array}{c}X t \\
\left(g^{-1}\right)\end{array}$ & $\begin{array}{l}P(3 \mathrm{HB}) \\
\left(\mathrm{g} \mathrm{L}^{-1}\right)\end{array}$ & $\begin{array}{c}\text { ACUMULATED P(3HB) } \\
(\%)\end{array}$ \\
\hline 7 & 6.1 & 23.9 & 36.0 & 9.3 & 3.99 & 42.86 \\
\hline 8 & 23.9 & 23.9 & 36.0 & 9.2 & 3.89 & 42.33 \\
\hline 9 & 15.0 & 15.0 & 28.0 & 6.6 & 2.15 & 32.52 \\
\hline 10 & 15.0 & 15.0 & 38.0 & 9.6 & 6.89 & 71.74 \\
\hline 11 & 15.0 & 0 & 33.0 & 1.2 & 0.32 & 26.43 \\
\hline 12 & 15.0 & 30.0 & 33.0 & 10.9 & 5.26 & 48.26 \\
\hline 13 & 0 & 15.0 & 33.0 & 7.0 & 2.13 & 30.38 \\
\hline 14 & 30.0 & 15.0 & 33.0 & 8.8 & 3.26 & 37.06 \\
\hline 15 & 15.0 & 15.0 & 33.0 & 8.6 & 3.07 & 35.73 \\
\hline 16 & 15.0 & 15.0 & 33.0 & 8.5 & 3.31 & 38.96 \\
\hline 17 & 15.0 & 15.0 & 33.0 & 8.7 & 3.68 & 42.31 \\
\hline
\end{tabular}

A variance analysis (ANOVA) was conducted for $\mathrm{P}(3 \mathrm{HB})$ production. Through an estimation of the $\mathrm{p}$ value supplied by ANOVA, it was verified that from the variables tested, only the inverted sugar concentration and the incubation temperature showed significant influence both on $\mathrm{P}(3 \mathrm{HB})$ production as well as on the polymer accumulation percentage. The glycerol concentration and the interactions were not statistically significant. The coefficients and their interactions are part of the model to form the response surface and are presented in Equations 1 and 2, the terms in bold print are statistically significant.

$$
\begin{aligned}
& P(3 H B)=3.435+0.108 *[G]-0.501 *[G]^{2}+\mathbf{1 . 2 1 5} *[\mathbf{A i}]-0.468 *[A i]^{2}+\mathbf{0 . 9 0 0} * \boldsymbol{T}+0.144 * \\
& T^{2}-0.131 *[G] *[A i]+0.082 *[G] * T+0.231 *[A i] * T
\end{aligned}
$$

$$
\begin{aligned}
& \text { Accumulation }=39.874+0.672 *[G]-0.487 *[G]^{2}+\mathbf{7 . 9 7 2} *[\text { Ai }]-3.513 *[A i]^{2}+7.733 * \boldsymbol{T}+ \\
& 1.724 * T^{2}-1.539 *[G] *[A i]+0.775 *[G] * T+0.556 *[A i] * T
\end{aligned}
$$

where: $\mathrm{P}(3 \mathrm{HB})$ : poly(3-hydroxybutyrate) concentration; $[\mathrm{G}]$ : glycerol ( $\mathrm{g} \mathrm{L}^{-1}$ ) concentration; [Ai]: inverted sugar $\left(\mathrm{g} \mathrm{L}^{-1}\right)$ concentration; $\mathrm{T}$ : temperature $\left({ }^{\circ} \mathrm{C}\right)$.

As the model is predictive in the experimental region, the response surfaces for $\mathrm{P}(3 \mathrm{HB})$ production are presented in Fig. 1 in relation to the inverted sugar concentration and incubation temperature within the interval tested, maintaining the glycerol concentration at $0 \mathrm{~g} \mathrm{~L}^{-1}$ (1a) and $15 \mathrm{~g} \mathrm{~L}^{-1}(1 \mathrm{~b})$. Similar profiles are observed on surfaces that represent the polymer accumulation percentage (data not presented).

As can be observed in Fig. 1a and $1 \mathrm{~b}$, the incubation temperature exerts significant influence on polymer production. Schneider (2006) [15] observed in his work, using the same culture medium, although with the addition of vegetable oils instead of glycerol, that an increase in temperature from 30 to $37^{\circ} \mathrm{C}$ raised $\mathrm{P}(3 \mathrm{HB})$ production. It can be verified that when glycerol is present in a concentration of $15 \mathrm{~g} \mathrm{~L}^{-1}$ (Fig. 1b) it reaches a production of $6.9 \mathrm{~g} \mathrm{~L}^{-1}$ as opposed to $5.3 \mathrm{~g} \mathrm{~L}^{-1}$, under the best conditions, without the addition of glycerol, even when the glycerol concentration is not statistically significant. On adding $15 \mathrm{~g} \mathrm{~L}^{-1}$ of glycerol the $\mathrm{P}(3 \mathrm{HB})$ accumulated percentage went from 50 to $65 \%$, a higher accumulation than that found by Cavalheiro et al. (2009) [16] who obtained $62 \%$ accumulation using the same micro-organism in fed batch process using glycerol as a carbon source. 

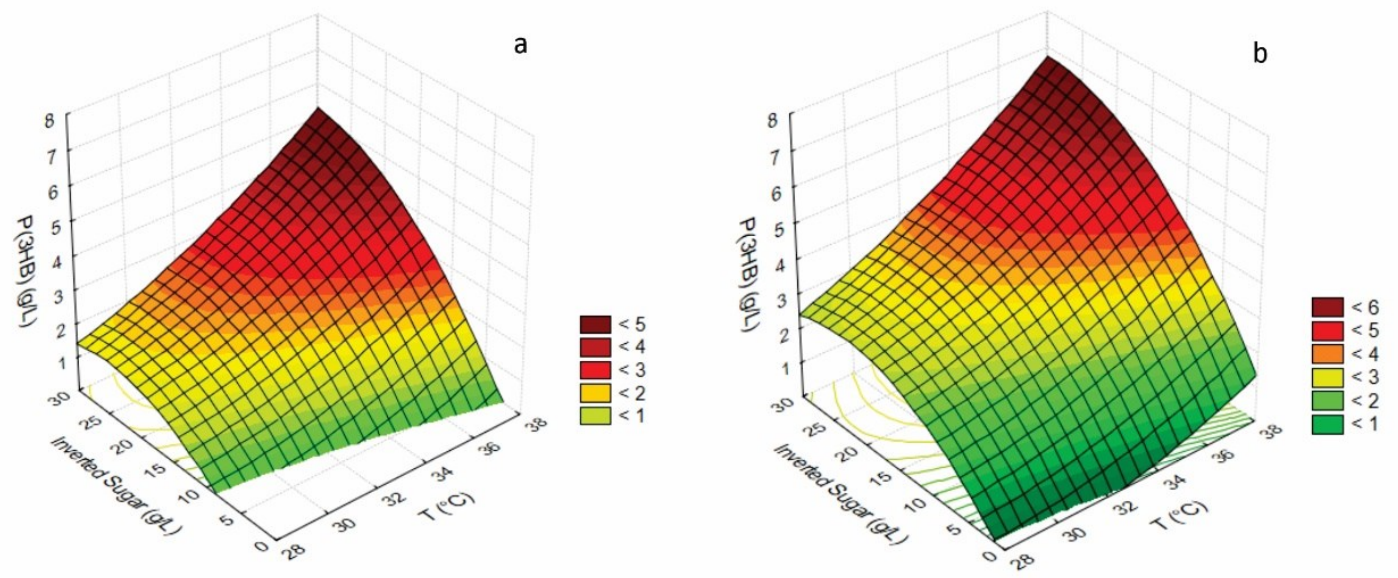

Figure 1: Response surfaces for $\mathrm{P}(3 \mathrm{HB})$ production in relation to the inverted sugar concentration $\left(\mathrm{g} \mathrm{L}^{-1}\right)$ and incubation temperature $\left({ }^{\circ} \mathrm{C}\right)$. (a) without glycerol and (b) glycerol concentration equal to $15 \mathrm{~g} \mathrm{~L}^{-1}$.

Through the design analysis, the ideal condition for validation was reached, in triplicate, the temperature at a high axial level $\left(38^{\circ} \mathrm{C}\right)$ and the inverted sugar concentration also at a high axial level $(30 \mathrm{~g}$ $\mathrm{L}^{-1}$ ) and glycerol at a low axial level (without glycerol), since the variance analysis shows that the glycerol concentration exerts no significant influence on either $\mathrm{P}(3 \mathrm{HB})$ production or on the polymer accumulation percentage in cells. Even without indicating the addition of glycerol as a significant variable, it cannot be denied that a $15 \%$ increase in polymer production is not interesting from an operating point of view in the extraction phase of this polymer. Added to this, it is not known at this time what the real contribution of adding glycerol is in terms of properties that the polymer can acquire, since the volume of the medium in the Erlenmeyer flasks is not sufficient to perform the extraction of the films for their thermal and mechanical characterization analyses. Thus it was decided to perform the model validation assays, in triplicate, not only with the predictive condition as the best but also under the conditions that in spite of not having indicated the glycerol concentration as a significant variable presented interesting responses for $\mathrm{P}(3 \mathrm{HB})$ production, which were the following: $38^{\circ} \mathrm{C}, 15 \mathrm{~g} \mathrm{~L}^{-1}$ of inverted sugar and $15 \mathrm{~g} \mathrm{~L}^{-1}$ of glycerol and $38^{\circ} \mathrm{C}, 30 \mathrm{~g} \mathrm{~L}^{-1}$ of inverted sugar and $15 \mathrm{~g} \mathrm{~L}^{-1}$ glycerol.

In Fig. $2 \mathrm{a}, 2 \mathrm{~b}$ and $2 \mathrm{c}$ the growth kinetics of Cupriavidus necator DSM 545 and $\mathrm{P}(3 \mathrm{HB})$ production are presented for the above mentioned conditions and Fig $2 \mathrm{~d}$ shows a comparison between the values predicted by the model and those obtained experimentally to production and the accumulated percentage of $\mathrm{P}(3 \mathrm{HB})$ in the biomass. Table 2 presents some kinetic parameters for the three assays performed in the validation of the central composite rotational design.

The $\mathrm{P}(3 \mathrm{HB})$ production reached $4.6 \pm 1.0 \mathrm{~g} \mathrm{~L}^{-1}$ representing a total accumulation of $48.9 \%$ of $\mathrm{P}(3 \mathrm{HB})$ inside the cells after $24 \mathrm{~h}$, without glycerol in the medium. When $15 \mathrm{~g} \mathrm{~L}^{-1}$ of inverted sugar and $15 \mathrm{~g} \mathrm{~L}^{-1}$ of glycerol were used as substrates $4.3 \pm 0.8 \mathrm{~g} \mathrm{~L}^{-1}$ was reached, representing a total accumulation of $51.1 \%$ of $\mathrm{P}(3 \mathrm{HB})$ and when the culture was started with $30 \mathrm{~g} \mathrm{~L}^{-1}$ of inverted sugar and $15 \mathrm{~g} \mathrm{~L}^{-1}$ of glycerol as substrate, maximum $\mathrm{P}(3 \mathrm{HB})$ concentration was $\left(7.3 \pm 1.4 \mathrm{~g} \mathrm{~L}^{-1}\right)$ representing an accumulation of $68.0 \%$ of $\mathrm{P}(3 \mathrm{HB})$ in the biomass. Ganesh et al. (2015) [17] cultivated E. coli for $96 \mathrm{~h}$ and obtained $1.47 \mathrm{~g} \mathrm{~L}^{-1}$ of PHB (28.8\% accumulation) using $20 \mathrm{~g} \mathrm{~L}^{-1}$ of crude glycerol and $4.58 \mathrm{~g} \mathrm{~L}^{-1}$ of PHB (54,5\% accumulation) when $20 \mathrm{~g} \mathrm{~L}^{-1}$ of pre-treated glycerol was used.

As can be observed in Fig. $2 \mathrm{~d}$ the values predicted for the accumulation of $\mathrm{P}(3 \mathrm{HB})$ are confirmed experimentally, when taking the experimental error into account. As for $\mathrm{P}(3 \mathrm{HB})$ production values, the model was confirmed experimentally for the two conditions in which the initial sugar concentration was $30 \mathrm{~g}$ $\mathrm{L}^{-1}$, with and without glycerol. Only in the culture in which there was $15 \mathrm{~g} \mathrm{~L}^{-1}$ of each one of the substrates did the predicted and experimentally observed values differ by only $3 \%$, considering the experimental error margin. 
$\mathbf{a}$

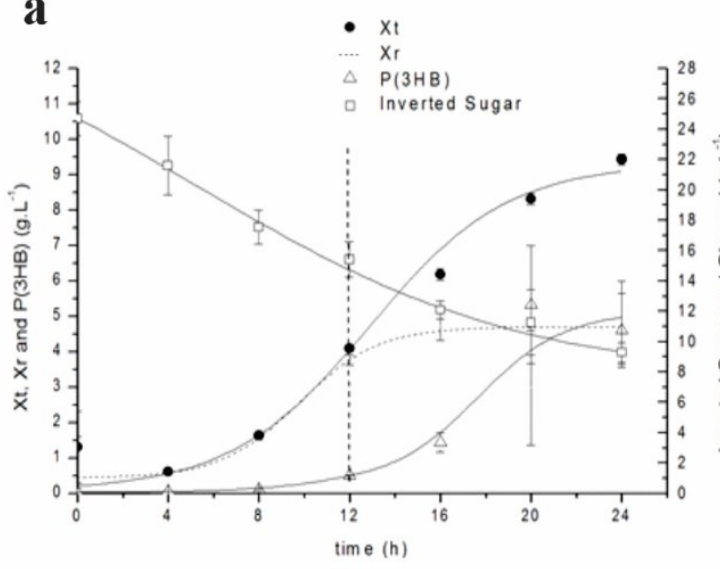

C

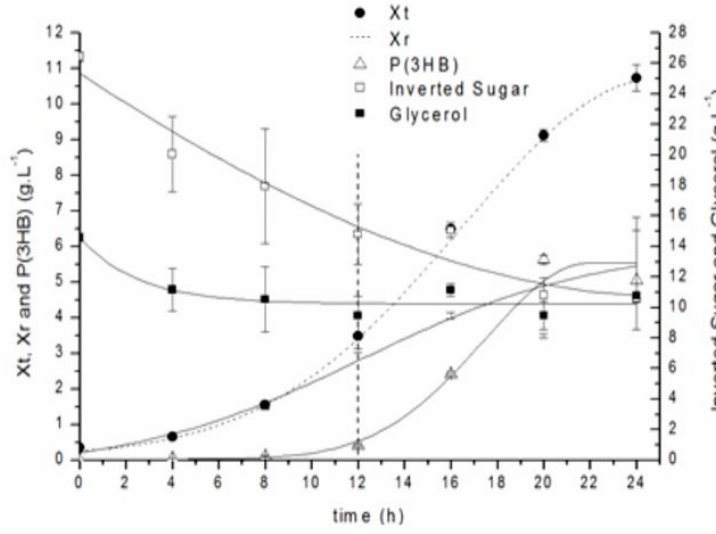

b

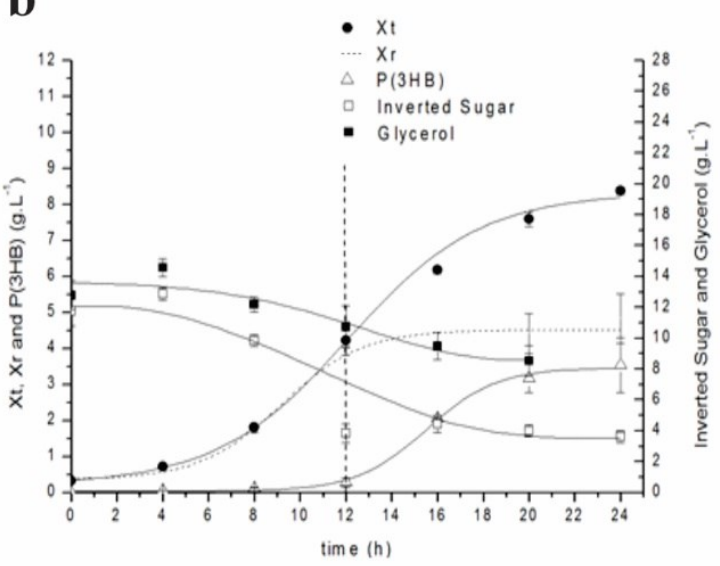

d

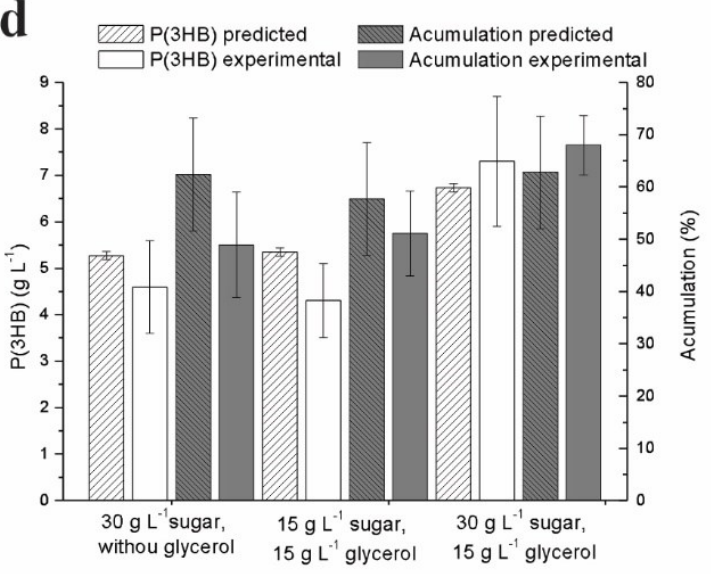

Figure 2: Growth kinetics of Cupriavidus necator DSM 545 and $\mathrm{P}(3 \mathrm{HB})$ production at $38{ }^{\circ} \mathrm{C}$, using $30 \mathrm{~g} \mathrm{~L}^{-1}$ of inverted sugar as substrate (a); using $15 \mathrm{~g} \mathrm{~L}^{-1}$ of inverted sugar and $15 \mathrm{~g} \mathrm{~L}^{-1}$ of glycerol as substrate (b) and using $30 \mathrm{~g} \mathrm{~L}^{-1}$ of inverted sugar and $15 \mathrm{~g} \mathrm{~L}^{-1}$ of glycerol as substrate (c). Comparison between the predictive values by the model for $\mathrm{P}(3 \mathrm{HB})$ production and the polymer accumulated percentage compared to the values obtained experimentally (d). Where $(\bullet)$ represents the total biomass $(\mathrm{Xt}),(\triangle)$ represents $\mathrm{P}(3 \mathrm{HB})$ production, (---) represents the residual biomass (Xr), $(\square)$ represents the inverted sugar concentration (Sugar) and (Ш) represents the glycerol concentration.

Table 2: Biomass values, $\mathrm{P}(3 \mathrm{HB})$ concentration, $\mathrm{P}(3 \mathrm{HB})$ accumulated percentage, cell productivity, $\mathrm{P}(3 \mathrm{HB})$ productivity, substrate conversion factors in cells and substrate in $\mathrm{P}(3 \mathrm{HB})$ for the different concentrations of the medium carbon source.

\begin{tabular}{l|l|l|l}
\hline \multirow{2}{*}{ KINETIC PARAMETER } & \multicolumn{3}{|c}{ ASSAY } \\
\cline { 2 - 4 } & $\begin{array}{l}\text { 30 } \mathrm{g} \mathrm{L}^{-1} \text { OF } \\
\text { INVERTED SUGAR }\end{array}$ & $\begin{array}{l}\text { 15 } \mathrm{g} \mathrm{L}^{-1} \text { OF INVERTED } \\
\text { SUGAR AND 15 } \mathbf{~ L ~}^{-1} \text { OF } \\
\text { GLYCEROL }\end{array}$ & $\begin{array}{l}\text { 30 g L } \\
\text { SUGAR OND 15 } \mathrm{g} \mathrm{L}^{-1} \text { OF } \\
\text { GLYCEROL }\end{array}$ \\
\hline $\mathrm{Xt}\left(\mathrm{g} \mathrm{L}^{-1}\right)$ & $9.4 \pm 0.2$ & $8.4 \pm 0.1$ & $10.7 \pm 0.4$ \\
\hline $\mathrm{Xr}\left(\mathrm{g} \mathrm{L}^{-1}\right)$ & $4.8 \pm 1.1$ & $4.1 \pm 0.7$ & $3.4 \pm 1.2$ \\
\hline $\mathrm{P}(3 \mathrm{HB})\left(\mathrm{g} \mathrm{L}^{-1}\right)$ & $4.6 \pm 1.0$ & $4.3 \pm 0.8$ & $7.4 \pm 1.2$ \\
\hline Acumulated P(3HB) $(\%)$ & $48.9 \pm 10.1$ & $51.1 \pm 8.1$ & $68.0 \pm 5.7$ \\
\hline $\mathrm{PXr}\left(\mathrm{g} \mathrm{L}^{-1} \mathrm{~h}^{-1}\right)$ & 0.22 & 0.18 & 0.15 \\
\hline
\end{tabular}




\begin{tabular}{|c|c|c|c|}
\hline \multirow[b]{2}{*}{ KINETIC PARAMETER } & \multicolumn{3}{|c|}{ ASSAY } \\
\hline & $\begin{array}{l}30 \mathrm{~g} \mathrm{~L}^{-1} \text { OF } \\
\text { INVERTED SUGAR }\end{array}$ & $\begin{array}{l}15 \mathrm{~g} \mathrm{~L}^{-1} \text { OF INVERTED } \\
\text { SUGAR AND } 15 \mathrm{~g} \mathrm{~L}^{-1} \text { OF } \\
\text { GLYCEROL }\end{array}$ & $\begin{array}{l}30 \mathrm{~g} \mathrm{~L}^{-1} \text { OF INVERTED } \\
\text { SUGAR AND } 15 \mathrm{~g} \mathrm{~L}^{-1} \text { OF } \\
\text { GLYCEROL }\end{array}$ \\
\hline $\operatorname{PP}(3 \mathrm{HB})\left(\mathrm{g} \mathrm{L}^{-1} \mathrm{~h}^{-1}\right)$ & 0.20 & 0.19 & 0.32 \\
\hline $\mathrm{Yx} / \mathrm{s}\left(\mathrm{g} \mathrm{g}^{-1}\right)$ & 0.17 & 0.18 & 0.07 \\
\hline $\mathrm{YP}(3 \mathrm{HB}) / \mathrm{s}\left(\mathrm{g} \mathrm{g}^{-1}\right)$ & 0.69 & 0.59 & 0.58 \\
\hline
\end{tabular}

The experiment with $30 \mathrm{~g} \mathrm{~L}^{-1}$ of inverted sugar and $15 \mathrm{~g} \mathrm{~L}^{-1}$ of glycerol attained the greatest $\mathrm{P}(3 \mathrm{HB})$ concentration and accumulation inside the cell. The productivity in cells and the substrate conversion factor in polymer were higher in the assay where there was no glycerol in the medium, however, productivity in polymer was $37.5 \%$ higher when $15 \mathrm{~g} \mathrm{~L}^{-1}$ of glycerol was added as a co-substrate. The substrate conversation factors in $\mathrm{P}(3 \mathrm{HB})$ found in this work were $(0.69 \mathrm{~g}$ of $\mathrm{P}(3 \mathrm{HB})$ per $\mathrm{g}$ of substrate, in assay without glycerol, $0.59 \mathrm{~g}$ of $\mathrm{P}(3 \mathrm{HB})$ per $\mathrm{g}$ of substrate when $15 \mathrm{~g} \mathrm{~L}^{-1}$ of each substrate was used and $0.58 \mathrm{~g}$ de $\mathrm{P}(3 \mathrm{HB})$ per $\mathrm{g}$ of substrate when $30 \mathrm{~g} \mathrm{~L}^{-1}$ of inverted sugar and $15 \mathrm{~g} \mathrm{~L}^{-1}$ of glycerol were used as substrate), values higher than those found by Nickel et al. (2008) [18] of $0.21 \mathrm{~g}$ of $\mathrm{P}(3 \mathrm{HB})$ per g of glycerol, for $E$. coli mutant culture; Ibrahim \& Steinbüchel (2010) [19] who obtained $0.29 \pm 0.3 \mathrm{~g}$ of P(3HB) per g of glycerol cultivating Zobellella denitrificans and Mothes et al. (2007) [20] who obtained glycerol conversion factor in $\mathrm{P}(3 \mathrm{HB})$ of $0.14 \mathrm{~g} \mathrm{~g}^{-1}$ in Cupriavidus necator culture, all using glycerol as the single carbon source. It is possible to note that when glycerol is used as a substrate, the substrate conversion factor in the product is higher than those obtained when glycerol is used as the main carbon source, regardless of whether it is in crude or purified state.

\section{CONCLUSION}

Culture temperature and the inverted sugar concentration were the variables that exerted significant influence on the production and percentage accumulation of $\mathrm{P}(3 \mathrm{HB})$. The best results were obtained at $38{ }^{\circ} \mathrm{C}$ and with $30 \mathrm{~g} \mathrm{~L}^{-1}$ of inverted sugar. Although not statistically significant, the addition of $15 \mathrm{~g} \mathrm{~L}^{-1}$ of glycerol increased the $\mathrm{P}(3 \mathrm{HB})$ accumulation percentage by $15 \%$, being the assay which in kinetic terms reached the greatest productivity in polymer $0.32 \mathrm{~g} \mathrm{~L}^{-1} \mathrm{~h}^{-1}$.

\section{AKNOWLEDGEMENTS}

The authors wish to thank CNPq and FAP/UNIVILLE for financial assistance and scholarships at the beginning of the research.

\section{BIBLIOGRAPHY}

[1] ANDERSON, A.J., DAWES, E.A. "Occurrence, metabolism, metabolic role, and industrial uses of bacterial polyhydroxyalkanoates”, Microbiological Reviews, v. 54, n. 4, pp. 450-472, Dec. 1990.

[2] NONATO, R.V., MANTELATTO, P.E., ROSSEL, C.E.V., "Integrated production of biodegradable plastic, sugar and ethanol. Mini-Review", Applied Microbiology Biotechnology, v. 57, n. 1, pp. 1-5, Oct. 2001.

[3] GUMEL, A.M., ANNUA, M.S.M., HEIDELBERG, T., "Effects of carbon substrates on biodegradable polymer composition and stability produced by Delftia tsuruhatensis Bet002 isolated from palm oil mill effluent”, Polymer Degradation and Stability, v. 97, n. 8, pp. 1224-1231, Aug. 2012.

[4] VOGELSANGER, N., FORMOLO, M.C., PIRES, A.T.N., et al., "Blendas Biodegradáveis de P(3HB)/ PCL para Aplicação como Filmes para Agricultura", In: Anais do X Encontro de Química da Região Sul, Joinville, pp. 57, Joinville, 2002.

[5] BYROM, D., "Polymer synthesis by micro-organisms: technology and economics", Trends and Biotechnology, v. 5, n. 9, pp. 246-250, Sep. 1987.

[6] WILLIAMS, S.F., MARTIN, D.P., HOROWITZ, D.M., et al., "PHA applications: addressing the price performance issue I. Tissue Engineering”, International Journal of Biological Macromolecules, v. 25, n. 1-3, pp. 111-121, Jun. 1999. 
[7] MEDEIROS, I.L., MARACACINI, J.M.S.A., DUARTE, M.A.T., et al., "Inovação em materiais: estudo para desenvolvimento de escova dental a partir de polímeros biodegradáveis", Revista Matéria, v.10, n.1, pp. 1-7, Mar. 2005.

[8] SUAVE, J., DALlaGNOL, E.C., PEZZIN, A.P.T., et al., "Biodegradable microspheres of poly(3hydroxybutyrate/poly( $\varepsilon$-caprolactone) loaded with malathion pesticide: preparation, characterization and in vitro controlled release test", Journal of Applied Polymer Science, v. 117, n. 6, pp. 3419-3427, Sep. 2010.

[9] VENKATESWAR REDDY, M., MAWATARY, Y., YAJIMA, Y., et al., "Production of poly-3hydroxybutyrate (P3HB) and poly(3-hydroxybutyrate-co-3-hydroxyvalerate) $\mathrm{P}(3 \mathrm{HB}-\mathrm{co}-3 \mathrm{HV})$ from synthetic wastewater using Hydrogenophaga palleronii", Bioresource Technology, v. 215, pp. 155-162, Sep. 2016.

[10] FRADINHO, J.C., OEHMEN, A., REIS, M.A.M., "Photosynthetic mixed culture polyhydroxyalkanoate (PHA) production from individual and mixed volatile fatty acids (VFAs): Substrate preferences and cosubstrate uptake", Journal of Biotechnology, v. 185, pp. 19-27, Sep. 2014.

[11] LEE, S.Y., CHANG, H.N., "Production of Poly(hydroxyalkanoic acid). Review", Adv Biochem Eng Biotechnology, v. 52, pp. 28-57, 1995.

[12] SILVA, G.P., MACK, M., CONTIERO, J., "Glycerol: a promising and abundant carbono source for industrial microbiology”, Biotecnology Advances, v. 27, n. 1, pp. 30-39, Jan-Feb. 2009.

[13] BRAUNNEG, G., SONNLEITNER, B., LAFFERTY, R.M., “A rapid gas chromatographic method for the determination of poly-ß-hydroxybutyric acid in microbial biomass", European Journal of Applied Microbiology and Biotechnology, v. 6, n. 1, pp. 29-37, Mar. 1978.

[14] BRANDL, H., BACHOFEN, R., MAYER, J., et al., "Minireview: Degradation and applications of polyhydroxyakanoates”, Canadian Journal of Microbiology, v. 41, n.1, pp. 143-153, 1995.

[15] SCHNEIDER, A.L.S., Síntese, caracterização e biodegradação de poli-3-hidroxibutirato - P(3HB) de Ralstonia eutropha e blendas de $\mathrm{P}(3 \mathrm{HB}) / \mathrm{PCL}$ (poli- $\varepsilon$-caprolactona). Florianópolis. Tese de D.Sc., Universidade Federal de Santa Catarina-UFSC, Florianópolis, SC, Brasil, 2006.

[16] CAVALHEIRO, J.M.B.T., ALMEIDA, M.C.M.D., GRANDFILS, C., et al., "Poly(3-hydroxybutyrate) production by Cupriavidus necator using waste glycerol", Process Biochemistry, v. 44, n. 5, pp. 509-515, May. 2009.

[17] GANESH, M., SENTHAMARAI, A., SHANMUGHAPRIYA, S., et al., "Effective production of low crystallinity Poly(3-hydroxybutyrate) by recombinant E. coli strain JM109 using crude glycerol as sole carbon source", Bioresource Technology, v. 192, pp. 677-681, Sep. 2015.

[18] NICKEL, P.I., PETTINARI, M.J., GALVAGNO, M.A., et al., "Poly(3-hydroxybutyrate) synthesis from glycerol by a recombinant Escherichia coli arcA mutant in fed-batch microaerobic cultures", Applied Microbial and Cell Physiology, v. 77, n. 6, pp. 1337-1343, 2008.

[19] IBRAHIM, M.H.A., STEINBÜCHEL, A., “Zobellella denitrificans strain MW1, a newly isolated bacterium suitable for poly(3-hydroxybutyratre) production from glycerol", Journal of Applied Microbiology, v. 108, n. 1, pp. 214-225, Jan. 2010.

[20] MOTHES, G., SCHNORPFEIL , C., ACKERMANN, J.-U., "Production of PHB from crude glycerol", Engineering in Life Sciences, v. 7, n. 5, pp. 475-479, Oct. 2007. 